\title{
Inappropriate secretion of antidiuretic hormone in pneumonia
}

\author{
RichaRd ChaRles \\ B.Sc., M.B., Ch.B., M.R.C.P.
}

\author{
J. RusSELl ReES \\ M.A., M.D., F.R.C.P.
}

\section{Bristol General Hospital, Bristol 2}

\begin{abstract}
Summary
Non-tuberculous pneumonia is an extremely rare cause of the syndrome of inappropriate secretion of antidiuretic hormone (ADH). A patient is described who had lobar pneumonia presenting as an acute confusional state due to hyponatraemia resulting from this cause.
\end{abstract}

\section{Introduction}

Since the original description of the syndrome of inappropriate ADH secretion in carcinoma of the bronchus (Schwartz et al., 1957) a wide variety of associated conditions has been found. An association with tuberculosis of the lung (Weiss and Katz, 1965; Vorherr et al., 1970) is now established but its occurrence in non-tuberculous pneumonia is extremely rare. Single cases of dilutional hyponatraemia have been described during the course of pneumococcal (Overholt, 1968) and staphylococcal (Stormont and Waterhouse, 1962; Rosenow, Segar and Zehr, 1972) pneumonia. In the present case, however, the effect of severe hyponatraemia was the dominant feature at presentation.

\section{Case history}

A 49-year-old chronic bronchitic was admitted with increasing mental confusion and a 2-day history of productive cough and purulent sputum. On admission he appeared ill with mild cyanosis. He was unable to give an account of himself and rapidly became more confused and disorderly requiring physical restraint. His temperature was $99 \cdot 8^{\circ} \mathrm{F}$; pulse $120 / \mathrm{min}$; respirations $40 / \mathrm{min}$; blood pressure $140 / 100 \mathrm{mmHg}$. Venous pressure was normal and there was no oedema. Clinical and radiological examination revealed extensive pneumonic consolidation of the right lower lobe (Fig. 1) and treatment was started with intramuscular benzylpenicillin $1 \mathrm{Mu}$ 6-hourly and streptomycin $1 \mathrm{~g}$ twice daily.

Investigations on admission gave the following results: serum sodium $108 \mathrm{mEq} / \mathrm{l}$, chloride 76 $\mathrm{mEq} / \mathrm{l}$, potassium $2.9 \mathrm{mEq} / 1$, bicarbonate $23 \mathrm{mEq} / \mathrm{l}$, blood urea $21 \mathrm{mg} / 100 \mathrm{ml}$, urine sodium $24 \mathrm{mEq} / 1$ ( $30 \mathrm{mEq}$ in first $24 \mathrm{hr}$ ), serum osmolality $240 \mathrm{mmol} /$ $\mathrm{kg}$, urine osmolality $520 \mathrm{mmol} / \mathrm{kg}$. Sputum microscopy revealed Gram-positive cocci but no significant pathogens were cultured.
In view of the severity of symptoms, an intravenous infusion of sodium $300 \mathrm{mEq}$, potassium 40 $\mathrm{mEq}$, and bicarbonate $100 \mathrm{mEq}$ was given over $1 \mathrm{~h}$ with dramatic improvement. Subsequent fluid restriction to cover the preceding 24-hr urinary and insensible losses together with a normal diet supplemented by sodium $100 \mathrm{mEq}$ and potassium $40 \mathrm{mEq}$ orally daily for 2 weeks corrected the serum electrolytes (Fig. 2). Antibiotic treatment was continued for 3 weeks. Sputum cytology and bronchoscopy showed no evidence of malignancy.

Subsequent investigations to exclude renal and adrenal disease including creatinine clearance, plasma cortisol and water load excretion were normal. At follow-up 14 months after admission he was well with normal serum electrolytes and a normat chest X-ray.

\section{Discussion}

In the normally hydrated subject administration of ADH results in prompt water retention, plasma dilution and after 2 or 3 days an increase in the urinary excretion of sodium and chloride (Leaf $e t$ al., 1953). The clinical features of the syndrome of inappropriate $\mathrm{ADH}$ secretion are thus a low plasma sodium and osmolality associated with urine which is hypertonic to plasma in the absence of dehydration, adrenal disease, or conditions involving over-expansion of the extracellular fluid volume. Estimation of ADH is not yet widely available and these criteria are sufficient to establish the diagnosis without demonstrating an elevated ADH concentration.

The onset of the syndrome in pneumonia is rapid but its pathogenesis is unknown. The hormone is produced directly by some tumours and by tukerculous lung (Vorherr et al., 1970) so it is possible that a substance with ADH-like activity is released from the infected tissue. Rosenow et al. (1972) suggests that hypoxic pulmonary vasoconstriction and a reduced cardiac output in pneumonia lead to stimulation of left atrial 'volume receptors' and release of $\mathrm{ADH}$. However, direct evidence for reduced left atrial filling in pneumonia, or for a relationship between left atrial pressure and ADH secretion in man is lacking.

Recognition of the syndrome is of considerable 


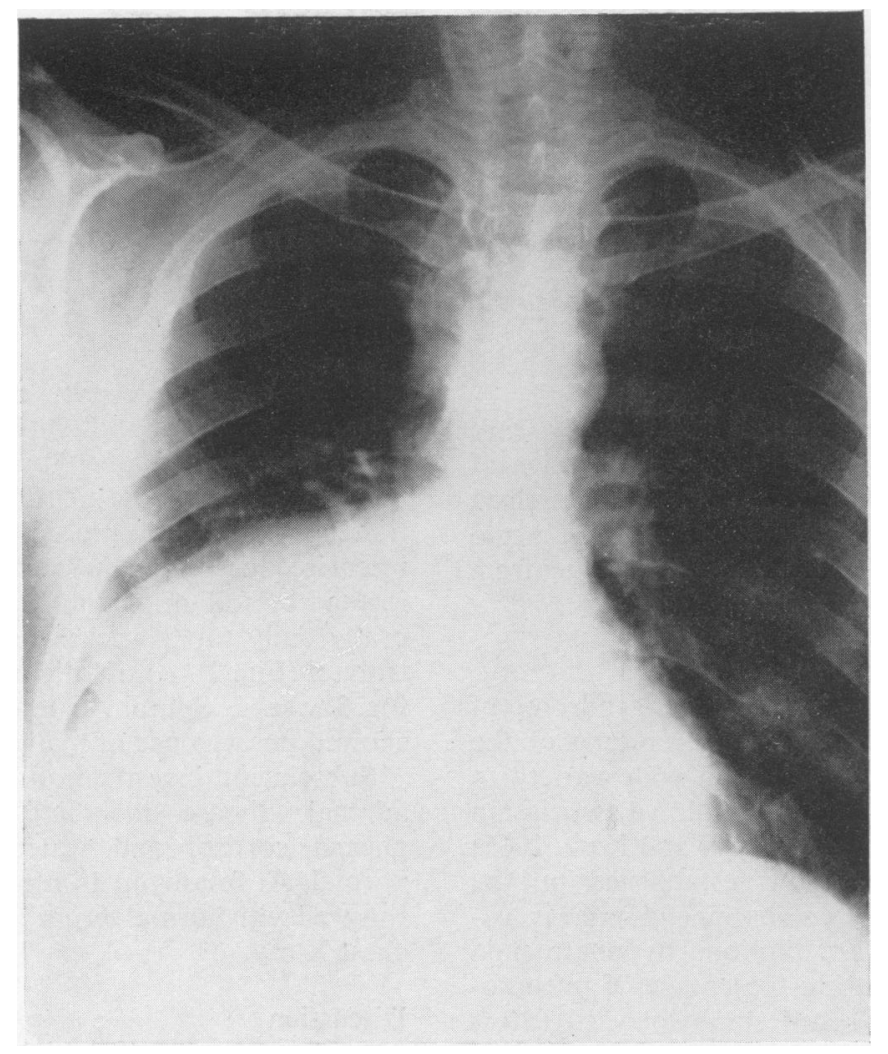

Fig. 1.

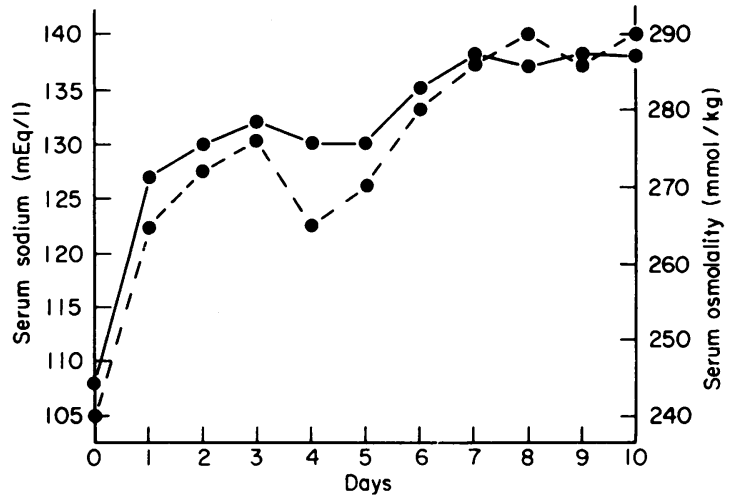

Fig. 2. Effect of treatment of serum sodium (-) and serum osmolality $(----)$.

practical importance. Fluid restriction alone will correct the serum electrolyte abnormality but when the serum sodium falls below $115 \mathrm{mEq} / \mathrm{l}$ the patient becomes increasingly confused and coma or convulsions may result in death. Thus more rapid correction with hypertonic saline may be required and can produce marked improvement in clinical condition. Furthermore, the association of an opacity in the lung with the syndrome of inappropriate ADH secretion need not imply carcinoma and should be vigorously treated so that a firm diagnosis can be established.

\section{References}

Leaf, A., Barter, F.C., Santos, R.F. \& Wrong, O. (1953) Evidence in man that urinary electrolyte loss induced by pitressin is a function of water retention. Journal of Clinical Investigation, 32, 868.

OVERHOLT, E.L. (1968) Water intoxication: its diagnosis and management. Military Medicine, 133, 607.

Rosenow, E.C., Segar, W.E. \& ZeHR, J.E. (1972) Inappropriate antidiuretic hormone secretion in pneumonia. Mayo Clinic Proceedings, 47, 169.

Schwartz, W.B., Bennett, W., Curelop, S. \& Bartter, F.C. (1957) A syndrome of renal sodium loss and hyponatremia probably resulting from inappropriate secretion of antidiuretic hormone. American Journal of Medicine, 23, 529.

Stormont, J.M. \& Waterhouse, C. (1962) Severe hyponatraemia associated with pneumonia. Metabolism, 11, 1181.

Vorherr, H., Massry, S.G., Fallet, R., Kaplan, L. \& KleEman, C.R. (1970) Antidiuretic principle in tuberculous lung tissue of a patient with pulmonary tuberculosis and hyponatremia. Annals of Internal Medicine, 72, 383.

WEISS, H. \& KATZ, S. (1965) Hyponatremia resulting from apparently inappropriate secretion of antidiuretic hormone in patients with pulmonary tuberculosis. American Review of Respiratory Disease, 92, 609. 